\title{
MEDIA FRAMING OF PRESIDENT MUHAMMADU BUHARI'S HUMAN RIGHTS ABUSES: A STUDY OF THE PUNCH, VANGUARD, THE NATION AND DAILY TRUST NEWSPAPERS
}

\author{
Silas Udenze (a), Barth Oshionebo (b), Stanislaus O. Iyorza (c) \\ (a) University of Abuja. Abuja, Nigeria. Email: udenzes[at]gmail.com \\ (b) University of Abuja. Abuja, Nigeria. Email: oshionebo.barth[at]uniabuja.edu.ng \\ (c) University of Calabar. Calabar, Nigeria. Email: starmorji[at]yahoo.com
}

\begin{abstract}
This study explores how four Nigerian newspapers framed President Muhammadu Buhari's administration and its human rights campaign. Using newspaper editorials published in The Punch, The Nation, Daily Trust, and Vanguard newspapers of December 2019 as the object of analysis, the paper draws on the methodological context of such framing to investigate how the selected newspapers framed the human rights situation in Nigeria. This study asserts that those newspapers' editorials used varieties of framing methods, namely: "unrepentant dictator frame", "resistance frame", "indifference frame", "warning frame", and "sympathetic" frame to portray the government's disposition to human rights issues. Furthermore, the paper reveals that the Nigerian media is partisan when it comes to the struggle against human rights while their positions on national issues like the fight against human rights abuse are subject to ethnic and political influences, as evident in the Daily Trust editorial. The study also revealed that editorials can be used as essential tools to curtail the excess of government, precisely, to fight against the abuse of human rights. Finally, the paper recommends that newspaper publishers should limit their editorial influences in day-to-day administration of news outlet to engender objectivity, news balance and accuracy in order not to exacerbate the socio-political situation in a multi-ethnic society such as Nigeria.
\end{abstract}

Keywords

editorial; framing; human right; newspaper; Nigeria

This work is licensed under a Creative Commons «Attribution» 4.0 International License 


\title{
ОСВЕЩЕНИЕ В СМИ НАРУШЕНИЙ ПРАВ ЧЕЛОВЕКА СО СТОРОНЫ ПРЕЗИДЕНТА МУХАММАДУ БУХАРИ: НА МАТЕРИАЛАХ ГA3ET THE PUNCH, VANGUARD, THE NATION И DAILY TRUST
}

\author{
Удензе Силас (a), Ошионебо Барт (b), Йорза Станислаус (c) \\ (a) Университет Абуджы. Абуджа, Нигерия. Email: udenzes[at]gmail.com \\ (b) Университет Абуджы. Абуджа, Нигерия. Email: oshionebo.barth[at]uniabuja.edu.ng \\ (c) Университет Калабара. Калабара, Нигерия. Email: starmorji[at]yahoo.com
}

\section{Аннотация}

В этой статье исследуется, как четыре нигерийские газеты освещали деятельность администрации президента Мухаммаду Бухари и ее кампанию за права человека. Используя в качестве объекта анализа передовые статьи, опубликованные в газетах The Punch, The Nation, Daily Trust и Vanguard за декабрь 2019 года, статья опирается на методологический контекст примененных способов освещения материала, чтобы изучить, как определенные газеты поставили под угрозу (скомпрометировали) борьбу за права человека в Нигерии. В этом исследовании утверждается, что в передовых статьях этих газет использовались различные методы освещения материала (фрейминг), а именно: позиционирование смысловых рамок «нераскаявшегося диктатора», «сопротивления», «безразличия», «предостережения» и «сочувствия», чтобы отобразить отношение правительства к вопросам о правах человека.

Кроме того, в статье показано, что нигерийские СМИ позиционируют себя патриотичными, когда речь идет о баталиях, направленных против прав человека (вообще), в то время как их позиции по национальным вопросам, таким как борьба с нарушениями прав человека, подвержены этническим и политическим влияниям, как это видно из передовой статьи Daily Trust. Исследование также показало, что редакционные статьи могут использоваться в качестве важных инструментов для ограничения чрезмерной власти правительства; речь идет о борьбе с нарушениями прав человека. Наконец, статья рекомендует издателям газет ограничить свое редакционное влияние в повседневном управлении новостными выпусками, чтобы обеспечить объективность, сбалансированность новости и точности, дабы не усугубить социально-политическую ситуацию в полиэтническом обществе, таком как Нигерия.

\section{Ключевые слова}

редакционная статья (передовица); фрэйминг (способ освещения материалов); права человека; газета; Нигерия

Это произведение доступно по лицензии Creative Commons «Attribution» («Атрибуция») 4.0 Всемирная 


\section{INTRODUCTION}

The main function of the media is to inform the populace of happenings within their surroundings continually. Let us imagine a society without this essential function of the media; in fact, your guess is good as mine. The media is often described as the "watchdog" of the society: when it barks the people scamper to enquire what has happened or is happening. The media occupies a pivotal position in world affairs. As an essential agent of society, it serves the public by providing basic knowledge and information about events that affect them (Mboso \& Ezeh, 2019). The media is an integral part of governance in issues regarding human rights. The mass media have a function to perform in raising awareness about issues and calling attention to whatever threatens human rights. The media in Nigeria is part of the social institutions that influence events in the country through different media of coverage - print, broadcast, electronic, and even social media (Chime-Nganya, Ezegwu, \& Ezeji, 2017). Mboso and Ezeh (2019) believe that an important print medium of communication, newspapers, provide analyses, debates, and criticism of socio-political, economic, health, and a host of other issues to inform, educate and entertain readers. Besides, newspapers as medium provide the needed background relevant to the news stories, details in the events-oriented phenomenon, and analysis of the critical situation (Okorie \& Oyedepo, 2011).

The permanency, depth, and variety of reporting attributed to print media have made information recall - with more lasting impact - possible because they remember its messages and use them for their daily purposes and in decision making (Mboso \& Ezeh, 2019). Furthermore, not only do people acquire factual information about public affairs from newspapers, but readers also learn how much attention should be paid to a topic based on how the message is framed and what emphasis is placed on it in a newspaper.

Towards the end of 2019, particular issues that raised debates and controversies through media interpretation and counter-interpretations is The Punch's editorial of December 11, 2019, where the paper accused the President Mohammadu Buhari of human right abuse. Below is the lead from The Punch editorial:

\section{Headline: Buhari’s Lawlessness: Our stand}

As a symbolic demonstration of our protest against autocracy and military-style repression, $\mathrm{PUNCH}$ (all our print newspapers, The PUNCH, Saturday PUNCH, Sunday PUNCH, PUNCH Sports Extra, and digital platforms, most especially Punchng.com) will henceforth prefix Buhari's name with his rank as a military dictator in the 80s, Major General, and refer to his administration as a regime, until they purge themselves of their insufferable contempt for the rule of law. 
In response to the above editorial, On December 19, 2019, Daily Trust, another daily newspaper counters The Punch editorial, outlining its reasons for its stand:

\section{Editorial Headline: That Punch editorial}

...we believe that PUNCH went overboard in its reaction. It has the right to take a position on any issue, but to describe an elected government as a 'regime' and to refuse to recognize the president by his statutory title is an attempt to delegitimize an elected president and the government he heads. While it is sometimes difficult, by the nature of newspapers, to draw a sharp dividing line, PUNCH's stand crossed the boundary between journalism and activism and could cause problems for proper journalism practice in the future. Government, too, could retaliate and describe us not as newspapers or journalists but as opposition activists and detractors. Such a stance would impair and harm the pursuit of good journalism...

Other two newspapers, The Nation and Vanguard also presented their opinions on the subject matter. The Nation in its editorial of 15 December 2019 entitled "Unnecessary Distraction" condemned the acts of human rights abuse by the Buhari administration. Also, on December 24, 2019, a day after the release of Mr Omoyele Sowore and retired colonel Sambo Dasuki, Vanguard newspaper in its editorial, "At last, freedom for Dasuki, Sowore" reiterated how it has warned the president regarding the dwindling human rights abuse in the country. The authors purposively chose the month of December 2019 and the different newspapers and their editorials because of the period; the period witnessed heated accusations and counter-accusations.

This study investigates how the editorials of four national dailies framed this issue, in order to contribute to this research area by providing a proper understanding of the relationship that exists between the Nigerian press and the government and how the Nigeria press has mirrored the government in the eyes of the masses.

Framing is mainly about what information is genuinely salient; "to frame" means to select significant aspects of a particular reality and make them more salient within a news story (Entman, 1993). How news media reports a particular issue can influence and shape public opinion and debate. Consequently, the frame of news reporting and information conveyed to a large extent determines how the target audience interprets and feels about a particular issue, and what attitudes they have about the issue in question (Scheufele \& Tewksbury, 2007). 


\section{OBJECTIVES OF THE RESEARCH}

1. To ascertain what types of frames are portrayed in the newspapers editorials.

2. To investigate the indifferences in the frames of the editorials.

3. To determine whether there are ethnic/regional inclinations in the frames.

\section{RESEARCH QUESTIONS}

The following research questions guide the study. Also, the study provides answers to the research questions:

1. What types of frames do the editorials of the newspapers portray?

2. Are there differences in the frames found in the editorials of the newspapers?

3. Are there ethnic/regional inclinations in these frames?

\section{CONCEPTUAL FRAMEWORK: HUMAN RIGHTS}

According to Ofoegbu (2013), the earliest documents that assert individual rights such as the Magna Carta (1215), the English Bill of Rights (1689), the French Declaration on the Rights of Man and Citizen (1789) and the United States Constitution and Bill of Rights (1791) are the written precursors to many of today's human rights documents. In 1948, the United Nations General Assembly adopted and proclaimed the Universal Declaration of Human Rights. The ontological essence of man ascertains he is a being with value. The recognition of this intrinsic dignity and value shows the imperative inalienable rights of human beings. Those inviolable rights are the bases for justice and peace on earth. If the rights are neglected and disregarded, human existence will degenerate into barbarous acts that are antithetical to the human conscience.

Human rights then are inviolable, inalienable fundamental rights that a human person possesses inherently simply because he or she is a human being. Human rights are perceived as universal; that is, it is for every person. Riding on the context and the overriding objective sought, good governance has been said at various times to encompass full respect for human rights ('OHCHR | Resolutions on Good Governance and Human Rights', 2012). Obiorah and Onwughalu (2018) write that democratic governance is the process of establishing and sustaining an environment for participatory and responsive political processes and respect for the rights of the citizens.

It is paramount to state that the whole of Chapter Four of Nigeria's 1999 Constitution as Amended was devoted to fundamental human rights provisions. Besides, according to Amnesty International 2019 Report on Nigeria, 
the country has ratified 12 out of 16 United Nations Human Rights Instruments, and the regional level, Nigeria, has also ratified 6 out of 9 African Union Human Rights Instruments. However, there is an excellent disparity at the level of sincerity that these rights are protected by different countries. The above statement prompted Ranney (1975) to remark that, "the mere presence of formally guaranteed rights in any nation's constitution means at least that the framers, for whatever reason, deemed it desirable to pay at least lip-service and perhaps more to the idea of the rights of men".

\section{HUMAN RIGHTS, THE MEDIA, AND PRESIDENT MUHAM- MADU BUHARI ADMINISTRATION}

An enduring legacy of the Buhari military era (1983-1985), was the introduction of the War Against Indiscipline (WAI) which sought to inculcate public order and discipline, enthrone civic responsibility and curb lawlessness among Nigerians, which began with citizens adhering to proper queuing at bus stations and supermarkets under the watchful eyes of soldiers with horsewhips (Abubakre, 2017). As Head of State, Buhari promulgated the infamous Decree Number 4 of 1984, the Protection Against False Accusation Decree, which most scholars considered to be the most repressive media law ever enacted in the country. In tandem with Decree Number 4, there was a Decree Number 2, which vested vast powers of the Chief of Staff to arrest and detain without charges persons deemed to be a security risk to the nation for up to three months. Ogbondah (2011), however, notes that it was the trial and imprisonment of two journalists of The Guardian newspapers, Tunde Thompson and Nduka Irabor, which marked a critical turning point in the state-press relations during the Buhari regime.

Human rights records of past governments in Nigeria were apparently tainted by infractions and violations no doubt; however, the expectations of the masses were heightened by the change mantra of the current government regarding the protection of the rights of Nigerians under the present dispensation. In a democratic environment, the rule of law protects the rights of individuals, preserves order, and limits the powers of government. The reverse seems to be the situation in Nigeria; human rights are not respected. Extra-judicial killing, unlawful detention, and other series of human rights abuses are still prevalent (Obiorah \& Onwughalu, 2018). A Report by the United States Government published on the Premium Times of March 26, 2018, described Nigeria as a nation where corruption, official impunity, and gross human rights violations occur at will. According to the report, the terrorist group, Boko Haram, and the Nigerian Government are the worst culprits of human rights abuses in the country. 
Freedom House's (2018) annual survey of media independence describes Nigeria media landscape as "partly free". A large and vibrant private domestic media outlet frequently criticized the government, but critics reported being subjected to threats, intimidation, and sometimes violence. Security services, including the State Security Service (SSS) and police, occasionally arrest and detain journalists who criticized the government. Besides, army personnel, in some instances, threatened civilians who provide or were perceived to have provided information to journalists or NGOs on illegalities by the military ('Country Reports on Human Rights Practices', 2018). It is not a surprise that Reporters Without Borders (2019), ranks Nigeria as 120/180 countries in the 2019 World Press Freedom Index. The country is ranked 119 in the 2018 index. This indicates the decaying state of press freedom and human rights in the country.

On August 14, 2018, police arrested and detained Premium Times journalist, Samuel Ogundipe. The Premium Times had published a classified report submitted by Inspector General of Police Ibrahim Idris to Vice-President Yemi Osinbajo over State Security Service (SSS) conduct in barring the entrance to the National Assembly complex, reportedly in a bid to arrest Senate President Bukola Saraki. The police insisted Ogundipe reveal the source of the article, which he refused to do. He was released on bail on August 17, 2018 ('Country Reports on Human Rights Practices', 2018). In a public statement, the Premium Times reports, Ogundipe was secretly arraigned before a magistrate court without any legal representation and charged with criminal trespass and theft from the police. After about two years of incommunicado detention by the SSS without trial, access to a lawyer, or family visitation, a publisher of Bayelsa State-based tabloid, the Weekly Source, Jones Abiri, was released on bail in August 2018. The Committee to Protect Journalists (CPJ) (2018) reports that Abiri was charged of being a member of a Niger Delta militant group but was not officially charged and said Abiri's detention was in response to an essential coverage from the July 2016 edition of the Weekly Source. United States Department of State Country Reports on Human Rights Practices (2018) opines that following an open letter from the CPJ and remarkable public outcry, Abiri was arraigned and eventually released on bail. According to the journalist, he was blindfolded, held in an underground prison for most of the two years without medical access. Human Rights Watch (2019) writes that the government reintroduced a hate speech bill on November 12, 2019, that would have made the death penalty a possible punishment for hate speech. The death penalty provision was later deleted from the bill following immense public pressure.

Famous Shiite Islamic scholar and founder of the Islamic Movement of Nigeria (IMN), El ZakZaky, has been in detention since December 2015 when 
the Nigerian army and his followers had a confrontation in Zaria, Kaduna, state. Ever since, the group has had ugly confrontations with the country's security agents. In 2016, the court ordered his release, but it was not granted. In 2019, he was granted bail to seek medical attention abroad, but he returned after three days on the accusation of inhuman treatment and stringent security restrictions deployed at the medical facility. Similarly, a former National Security Adviser, Colonel Sambo Dasuki was arrested in December 2015 on the allegation of diverting state funds. Several courts granted bail to the accused, but the Federal Government disregarded the courts' pronouncements (See Figure 1). These resulted in numerous media outcry for the need for the government to respect the law. Coincidentally, the Federal Government released Colonel Sambo Dasuki and Omoyele Sowore, a Nigerian-American and the publisher of Sahara Reporters 13 days after The Punch editorial in the current study was published ('That PUNCH Editorial', 2019). Before now, Sowore was released on bail and was immediately arrested in court the next day, where he was scheduled to fulfill his bail condition ('DSS Re-Arrests, Detains Sowore', 2019). Sowore was picked up by the SSS on August 9, 2019, on the allegation of treason for calling for protest tagged "Revolution Now". Though the Federal Government claimed that they were released on compassionate grounds, media watchers believe that it was the result of constant media reportage. There are other journalists that are currently in detention for merely writing about the government, like the publisher of a privately owned news website Cross River Watch, Agba Jalingo ('Nigerian Publisher Agba Jalingo Charged with Treason', 2019).

There was an alarming legislative interest and calls for the regulation of social media due to the perceived concerns that it plays a role in accelerating rural and electoral violence. Before now, the National Assembly passed the Digital Rights and Online Freedom Bill in December 2017. The law seeks to provide fundamental digital freedoms and protections for citizens but was not expected, to clarify what constitutes hate speech ('Country Reports on $\mathrm{Hu}$ man Rights Practices', 2018). The government proposed the controversial bill tagged "Protection from Internet Falsehood and Manipulation Bill 2019". The bill forbids statements on social media deemed likely to be inimical to national security and those which may disparage the confidence of the masses in the government. It proffers that these offenses be punishable by a fine, a prison sentence of up to three years, or both. The bill also seeks to permit law enforcement agencies to order internet service providers to disable internet access (Ewang, 2019). A bill to control social media was first examined in 2015 but failed to pass into law after similar public outbursts. However, in the same year, the Cybercrimes law was ratified, criminalizing a broad range of online interactions. 


\section{METHODOLOGY}

The study investigates four Nigerian dallies, The Punch, The Nation, Daily Trust, and Vanguard. While it is pertinent to reiterate the Southwest region enjoys a heavy concentration of media organizations by virtue of the economic status of Lagos as the commercial hub of the country, it must be mentioned that newspaper ownership in Nigeria is domiciled mostly in the SouthSouth region of Nigeria and President Muhammadu Buhari is from the dominant northern region. Ciboh (2007) observes that the history of the Nigerian media is apparently linked to the Christian missionaries that arrived in the country through the Southern region. Nigeria's first newspaper, Iwe Iroyin fun Awon Ara Egba ati Yoruba (Newspaper for the Igbo and Yoruba), was established by Reverend Henry Townsend, a British missionary in 1859 to propagate evangelism although the paper later went into political issues of that time.

Ownership can also be traced to ethnic regionalism as observed during the colonial period when Nigerian nationalists used the press to champion Nigeria's independence as well as partisan politics in which nationalists were deeply involved in the post-independence period in a bid to sway public opinion. Daramola (2015) argues that media practitioners (Nnamdi Azikiwe, Obafemi Awolowo, Ernest Ikoli, Lateef Jakande, Moshood Kashimawu Abiola, etc.) were themselves politicians, noting that the first set of politicians who established political parties were newspaper publishers. Hence, for the current study, there is The Punch and the The Nation for the South-West region, Daily Trust for the northern region, Vanguard portrays nationalistic and neutral features.

All four newspapers have an online presence that can be accessed from any part of the globe. The newspapers' editorials were published in December $11,15,19$, and 24 of 2019, respectively. As stated earlier, for convenience sake, the unit of analysis is the newspaper editorials published by the newspapers $(\mathrm{n}=4)$. The selected sample was analyzed textually to examine the pattern of framing employed by each newspaper editorial as it concerns President Mohammadu Buhari's administration and its human rights challenge. The authors read each editorial at a minimum of five times each, while we searched for frames that best describes them. Besides, we adopted Ayres, Kavanaugh and Knafli (2003) within-case and cross-case qualitative approach to study the editorials. These methods allow the researchers to immerse themselves and also compare significant statements in each editorial while studying and reading them. 


\section{REVIEW OF RELATED WORK}

In a study of print media reportage of crisis, Ikenna (2008), employing the content analytical method, discovered that coverage of crisis by the Nigerian press is nothing but biased discourse orchestrated by sentiments. Furthermore, the study found that print media often reports crises in such a manner that breeds the conflicts. As one of its recommendations, the study cautions the print media to be fair and balance in their reportage of crisis. This assertion was affirmed by Hassan (2009) as he revealed in his study that the print media in Nigeria often relegate objective and fairness to the background whenever they are reporting crisis/conflicts. The study unveiled that the print media report crises in line with the interests of their publishers and ethnic affiliations. Similarly, Njoku (2010) revealed that the print media usually take sides by subjectively covering the conflicts.

In a 2013 study, Olorede, Oyewole, and Azeez employed the methodology of framing in studying press reportage of President Yar'Adua's ill-health in select Nigerian newspapers. The paper found that minimal attention had been given to the coverage of President Yar'Adua's ill-health by Nigerian newspapers. It was also found that the newspapers used emotional image frames to draw public attention and generate concern for the president's illhealth through the use of haggard-looking pictures. The study recommends that Nigerian Press should de-emphasize unnecessary concentration on crisis and sentiments. Odoemelam, Ncube, and Okorom (2014) analyzed frames in news discourse on Nelson Mandela's illness and hospitalization, in a study of Nigerian and Zimbabwean newspapers. The purpose of the study was to determine if there were major differences in frame choice that emerged in the coverage between the countries. The study ascertained that the coverage in the Nigerian newspaper was framed in terms of politics; e.g. Virtues of democracy, ethical leadership, and self-sacrifice as epitomized by Mandela's struggle against the racist apartheid system in South Africa, for which he went to prison for 27 years. The study affirmed that, during the time within which Nelson Mandela was hospitalized, Zimbabwean and Nigerian newspapers framed the event in different manners. The authors recommend the need for cross-national research on the frames adopted by the print media in covering issues across Africa.

In a research entitled "Evaluation of political news reportage in Nigeria's Vanguard and The Guardian", Brown and Udomisor (2015) investigate how political issues were treated in Nigeria's newspapers, by assessing the proportion of political news to other subject matters, the readers' interest given to political stories and the level of prominence attached to these stories by way of placement and prominence. The methods employed to obtain data for analysis in the study were documentary surveys and content analysis. Findings 
revealed that political issues were not given adequate attention in the two newspapers and were mostly tailored towards the government's interests. The paper recommends that the Nigerian newspapers should render vivid and unbiased reporting of political issues, as well as scale-up political contents in its publications as a way of consolidating political consciousness in Nigeria.

Abubakre (2017) studied The Nation, The Punch, The Guardian, Daily Sun, and Daily Trust editorials on the anti-corruption war on President Buhari's first year anniversary. The scholar found that while all the five newspapers acknowledged that Buhari has given liberty to the different anti-corruption agencies to do their job, the Daily Trust newspaper looked at it from a personal perspective. Its editorial reads that: "Buhari's reputation for incorruptibility and his total aversion to corrupt deeds has been cemented nationally and internationally with revelations his regime made of the sordid corruption under his predecessors". Also, The Nation newspaper was apparently in support of the president's anti-corruption drive. Further, the study ascertained that while The Guardian and The Punch editorials suggest that President Buhari's anti-corruption drive appears to be biased, and a battle against a few, The Daily Sun identified failure to get a conviction for individuals arraigned for corruption as raising "questions about the president's anti-corruption campaign". The study shows that the Nigerian Press is highly partisan as it pertains to the fight against corruption as it reveals that their position on national issues such as the fight against corruption is subject to ethnic and political influences.

As the reviews have shown, the media has a critical role to play in informing the citizens of political events and issues in society. None of the reviewed studies touched the topic of human rights. Besides, there is a considerable vacuum in the study of newspaper editorial as revealed in the studies reviewed; hence, this study attempts to fill these gaps.

\section{THE POWER OF EDITORIAL IN SOCIETY}

Ani and Anyandike (2013) define an editorial as a newspaper's opinion on critical socio-political, economic or legal issues that concern society, which is intended to persuade readers to agree to a particular point of view. Newspaper editorials are the views expressed by newspaper owners and/or editors of the medium. Duyile (2005) defines editorials as comments or arguments in support of a particular policy, an action, or an idea whether expressed or latent. It is the stands of the newspaper on contemporary political, social, or economic issues to inform their readers about what they think on such issues. It is usually written to persuade.

According to Ate (2006), editorial topics cannot emerge from the sky. It must be a current issue that has been reported and discussed in the media. 
Such issues must attract public attention and debate. Similarly, Ekeanyanwu and Jokodola (2009) also assert that editorials provoke debate and offer enlightened judgments to readers. Izadi and Saghaye-Biria (2007) note that, unlike news discourse, editorials mirror conversations among a society's economic and power elites, with the public being less of an addressee than spectators. It is therefore correct to say that editorials comprise of news and features elements. Editorials play significant roles in society in line with its relationship with public opinion, social responsibility, and agenda-setting principles. Anim and Sunday (2011) submit that editorials are essential elements in positioning newspapers as a mediator between the masses and the many contending forces in society. It was for this reason that newspapers set aside an identifiable section called the Editorial Page or Opinion Pages for their opinions.

Emery (1962) opines that the obligation of any newspaper to its community is to strive for honest and comprehensive coverage of the news and courageous expression of editorial opinion in support of the basic principles of human liberty and social progress. Editorials condemn or attack socio-political, economic, and moral ills of society. Editorials sometimes perform the function of a human rights activist, raising alarms on blatant abuse or annihilation of specific norms and acceptable social order in the society. Repressive government policies can be criticized by editorials. On the side of the masses, when a part of the society decides, for example, to take laws into its hand, an editorial is bound to attack such an anomaly. Editorials also defend the underdogs in society. In every given society, there exist diverse dimensions of economic groups - the rich, the haves, the have-nots, the powerful and the less powerful, the literate, and the illiterate, amongst others. When the rich, for example, tend to unjustly exploit and oppress the poor, editorials rise up in defense of the latter. The relationship among different members of the society is often monitored by the media, and advocacy roles are played by editorials to defend the course of the wretched of the earth. Given the abundance of literature available on other newspaper research, like audience research, news and features, editorials appear to have been relegated to the background in media discourse research. Elyazale (2014) corroborates this position as the contends that newspaper editorials deserve more consideration in media research given their unique attributes, in terms of their structure, precisely, the language and style used in crafting them.

\section{THEORETICAL FRAMEWORK: FRAMING THEORY}

This study employs Framing Theory to explore how select Nigerian newspapers frame their respective editorial positions on President Muhammadu Buhari's administration and its human right saga. This theory suggests 
that the way a piece of information is presented (framed) determines the way people comprehend such messages. Baran and Dennis (2009) opine that this theory examines the idea of how people use expectations to make sense of every (any person's) life. The basis for framing theory is that the media focus attention on specific issues and then place them within a field of meaning and interpretation to the masses. This theory is essential to our study because it explains how the editorials contribute in shaping perception of the Nigerian masses. Framing theory helps us to understand that the way Nigerians perceive the issue of Buhari's administration human right saga, to a large extent, is a result of how the media has "framed" their reports with respect to its activities.

Producers of media contents decide where and what to place emphasis on, what type of content is to be used in a story by choice of phrases, images, and positioning (Chime-Nganya et al., 2017). According to Morner and Olausson (as cited in Mboso \& Ezeh, 2019), framing is mostly about salient information, meaning that to frame is to select an aspect of perceived reality and make it more important in a communication text in a way that promotes a particular situation's definition, "causal interpretation, moral evaluation, and treatment recommendation" (Entman, 1993). A common characteristic in most approaches to framing is the belief that we do not relate to the world in a direct and unfiltered way, but that we recognize and interpret issues within existing ideas which we have created through other information sources (Mboso \& Ezeh, 2019).

Frame analysis has generally been used in studying news media texts (Morner \& Olausson, 2017; Abubakre, 2017; Chime-Nganya, Ezegwu \& Ezeji, 2017; Mboso \& Ezeh, 2019); and it is applicable to a wide range of textual materials (Morner \& Olausson, 2017). Frames are discernible in all forms of media: print, electronic, broadcast, and social media, and they convey meaning in the minds of the audience through interactions between readers and the message. McQuail 2005 (as cited in Mboso \& Ezeh, 2019) reiterates that there are varying framing devices used in media framing. Employing certain words or phrases, making specific contextual references, giving examples as typical, referring to specific sources amongst others are some examples of techniques which journalists use to frame issues.

\section{THE NEWSPAPERS UNDER STUDY: A BRIEF HISTORICAL OVERVIEW}

\section{The Punch}

According to nigeriafinder.com there are fifty-one (51) Nigerian newspapers that publish both offline (hardcopy) and online, while ninety-five (95) 
newspapers are solely online. All four newspapers under the current study are published both offline and online. Besides, the newspapers were chosen for the study because of their national outlook and geographical spread. Specifically, the dailies were chosen for the study because they were the only newspapers that were engaged in similar editorial banters in respect of the president's approach to human rights issues at the time of the study.

Punch Nigeria Limited was registered in 1970, under the Companies Act of 1968 to commence the business of publishing newspapers, magazines, and other periodicals of public interest. The paper was officially founded between 1971 and 1973 by two close friends, James Aboderin and Sam Amuka. The newspaper is one of Nigeria's most influential daily, with the current printrun estimated at 80,000 copies per day (Abubakre, 2017). The paper clinched the 'Newspaper of the Year' awards in 2015, 2016, and 2017 respectively, for the 'Diamond Awards for Media Excellence' (DAME). It claims to be Nigeria's most widely read newspaper. The paper is private-owned. To large extent, every newspaper has an interest it is projecting or protecting, The Punch newspaper is western Nigeria inclined but it is not apparent. It tries to maintain a balanced national outlook. The paper strives to be as liberal as it could; it does not hesitate in condemning or praising the government if the need arises.

\section{The Nation}

This paper is published by Vintage Press Limited. There are speculations that The Nation is owned by the national leader of the current government in power - All Progressive Congress, Ahmed Bola Tinubu. The paper was launched in 2006. The headquarters of the paper is located in Lagos, southwest, Nigeria. The paper claims not to beholden to any interest group and its loyalty is to the nation. Further, it claims to be the most read newspaper in Nigeria, and also the paper with the most nationalistic outlook.

\section{Daily Trust}

Daily Trust is a privately owned newspaper established by the Media Trust Limited in 1998. The Daily Trust, which is highly influential, and the largest circulating in Nigeria's Northern region, was launched in 2001, and its proprietor Kabiru Yusuf is the current President of Newspaper Proprietors' of Nigeria (NPAN). The paper's Mission Statement and Vision, respectively, reads: "To disseminate credible information for the good of all stakeholders" and "A world-class media company that earns public trust". It also publishes a Hausa language newspaper, Aminiya. The Hausa language is widely spoken in northern Nigeria; in fact, the language is like the region's lingua franca. Historically, the paper has always been pro-north; it supports the ideologies of the northern part of Nigeria, especially whenever the region is in the helm of affairs of the country. 


\title{
Vanguard
}

The paper is published by Vanguard Media Limited. The paper was established in 1984 by Mr. Sam Amuka, a renowned journalist. He was the editor of Sunday Times and the First Managing Director of the Punch Newspaper. The first copy of the Vanguard hit the newsstands as a weekly paper on Sunday June 3rd, 1984. The paper became daily on July 15, 1984. Today, the paper has on its stable: the Daily Vanguard, Saturday Vanguard and Sunday Vanguard. It has also added other titles that take care of specific interests. They are: Financial Vanguard, Allure, and Sweet Crude among others. It claims that its core values are equity and fairness, integrity, people- centeredness, and Excellence.

\section{FINDINGS AND DISCUSSIONS}

The current study focuses on four newspaper editorials: The Punch, The Nation, Daily Trust and Vanguard. Starting with The Punch, the choice of words in the headline of the article cited below indicates a necessary framing that suggests a problem of human rights abuse in the country. The editorial made references to past situations of human rights abuse under General Muhamadu Buhari when he was a military Head of State in 1984/85; hence, the frame "Unrepentant Dictator".

\begin{abstract}
...Major General Muhammadu Buhari (retd) ran a ham-fisted military junta in 1984/85 and old habits obviously run deep... This situation is eerily familiar: as military head of state, Buhari's appointee who headed the National Security Organisation, as the SSS was then known, Lawal Rafindadi, unleashed a reign of terror on Nigerians, featuring arbitrary arrests and torture in cells described by inmates as chambers of horror. Under the infamous Decree 2, agents had presigned detention papers, court orders were ignored and ouster clauses were inserted in decrees, while the press was specifically targeted with the infamous Decree 4 under which Tunde Thompson and Nduka Irabor were jailed. Returning as an elected president, Buhari has followed the same template...
\end{abstract}

The above frame corroborates the assertion that framing can increase the seriousness of a situation in the mind of the audience, and can consequently influence their attitudes towards the issue (Tewksbury \& Scheufele, 2009; De Swert \& Walgrave, 2012; Boukes, Boomgaarden, Moorman \& De Vreese, 2015). According to Papacharissi and Oliveria (2008), when the media place stories in specific frames, they lend a different meaning to the news. Therefore, media increase or decrease the prominence of issues, which permits the public to remember and make judgments on such issues. 


\title{
Resistance Frame
}

More so, The Punch editorial raised the need for the masses to confront and resist Buhari's abuse of human rights. Wholly, The Punch editorial performed the function of a human rights activist raising alarms on flagrant abuse or annihilation of specific norms and acceptable social order in the society as affirmed by Ate (2006). A part of The Punch editorial reads thus:

\begin{abstract}
...PUNCH views this tendency and its recent escalation with serious concern, knowing as the great thinker, Edmund Burke, said that "the only thing necessary for the triumph of evil is for good men to do nothing"... PUNCH will not adopt the self-defeating attitude of many Nigerians looking the other way after each violation of rights and attacks on the citizens, the courts, the press and civic society, including self-determination groups lawfully exercising their inalienable rights to peaceful dissent...
\end{abstract}

Besides, The Punch is widely popular among the people of the southwest region of Nigeria; hence, elite readers from other regions, precisely the northern may feel the paper's editorial is spiting the president. These findings may be in tandem with Mboso and Ezeh (2019) belief that framing has the potential to favor a social group or their issues without revealing bias. Consequently, media frames can taint a social group in order to attract hostile attitudes toward them, thereby becoming a catalyst for ethnic bigotry and hatemongering.

\section{Warning Frame}

A close study of Vanguard editorial reveals a potent "warning frame". Significant parts of the editorial highlight how it has cautioned the president in respect of the human rights abuse in the nation. These excerpts exemplify the position of the current editorial of this study.

We had cautioned the President Muhammadu Buhari government to jettison the idea that it would consider national security as superior to the rule of law...

...It is the constitution and the courts that have the power to dictate the ways by which we can protect the nation's interests and its security without violating the inalienable rights of the citizenry. We can never commend any arm of government that backtracks after riding roughshod over our democratic institutions and tenets unless it openly commits to mending its ways...

\section{Sympathetic Frame}

In the last paragraph of its editorial, though, Daily Trust admonishes the president and its agents to adhere to citizens' rights. However, the review of the editorial reveals a dominant sympathy for the administration of President Muhammadu Buhari. In a related study, Abubakre (2017) discovered a similar 
trend regarding Daily Trust newspaper. The choice of words the editorial employed in the description of Sowore whose detention was a vital part of The Punch editorial reveals the partisan and sympathetic feature of Daily Trust editorial:

...Sowore ran for president in the last general election. He polled 33,953 votes or 0.12 percent of the 28,614,190 votes cast. Soon afterward, he embarked on a protest tagged "Revolution Now", for which he was arrested and charged to court for treason...

Furthermore, the editorial made references to current aids of the president who are continually in quick responses to defend the administration:

...Presidential spokesman Femi Adesina said the newspaper's stand was proof of Buhari's commitment to free speech and press freedom. Senior Special Assistant to the President on Media and Publicity Garba Shehu in a separate statement accused the newspaper of 'personal hatred and animus' for the president. Presidential Advisory Committee Against Corruption chairman Prof. Itse Sagay described the editorial as disgraceful and disrespectful. Senior Advocate of Nigeria Dr Alex Izinyon said PUNCH's editorial policy was unconstitutional and that "despite the acts complained about, he remains the president”...

After making reference as exemplified above, Daily Trust made the assertion below:

...Everything considered, we believe that $\mathrm{PUNCH}$ went overboard in its reaction. It has the right to take a position on any issue, but to describe an elected government as a 'regime' and to refuse to recognize the president by his statutory title is an attempt to delegitimize an elected president and the government he heads...

It has often been said that the media is separable from the government. The above finding is in consonance with other studies (Brown and Udomisor, 2015; Njoku, 2010; Ikenna; 2008) that have reported media biases and sentiments when reporting events, especially political issues. Nigeria's media is shrouded in a socio-political, economic, and ethnic undertone. Being a paper with a predominantly northern allegiance, it may not be surprising for this study to uncover the sympathetic frame in the Daily Trust editorial.

\section{Indifference Frame}

Widely, it has been found that most media organizations have one interest or the other to protect. This is evident in the case of The Nation newspaper. The paper's editorial did not rightly condemn the administration of President Muhammadu Buhari without painting one of the captive, Mr Sowore, in bad light. The excerpt below is at the opening of the editorial; the paper was critical about the state of human rights abuse in the country. Having attacked the 
government, the paper did not spare one of the captives of human rights abuse, Mr. Sowore:

...Day followed day, and Omoyele Sowore was still behind bars. Week followed week, and it was no longer a matter of levity. ...The Buhari administration was now known to follow a familiar script. We are witnessing it in the cases of former National Security Adviser Sambo Dasuki and the Shiite leader Ibrahim el Zakzaky. Were we going to accept this jackboot style under a democracy?

...Sowore was a presidential candidate who lost because the electorate largely ignored him. A man, who was under investigation by his own party for financial opacity, was now vaulted into a conclave of heroes by a DSS that did not seem to understand the sociology of protests and the stature of those who could stir disaffection in the land...

\section{CONCLUSION/RECOMMENDATION}

The current paper explores the framing of Muhammadu Buhari's administration and its human right saga. The editorials of four newspaper were investigated in this regard- The Punch, The Nation, Daily Trust, and Vanguard . This study concludes, based on its findings, that the selected newspapers' editorial used varieties of frames: unrepentant dictator frame, resistance frame, warning frame, indifference frame and sympathetic frame. Furthermore, the reveals that the Daily Trust newspaper is on the side of the government in respect of issue human rights as it is revealed that their position on national issues like the fight against human rights abuse is subject to ethnic and political influences, On the other hand, The Nation is indifferent despite the papers close tie with the current government. The study has also revealed that editorials are critical tools that can be used to curtail the excess of government, precisely, to fight human rights abuse. The study recommends that newspaper publishers should reduce their editorial influences in day to day administration of news outlet in order to engender objectivity, news balance and accuracy. Besides, the sensitive attributes of human rights challenges should be taken into consideration by publishers in order not to exacerbate the situation in a multi-ethnic society like Nigeria. 


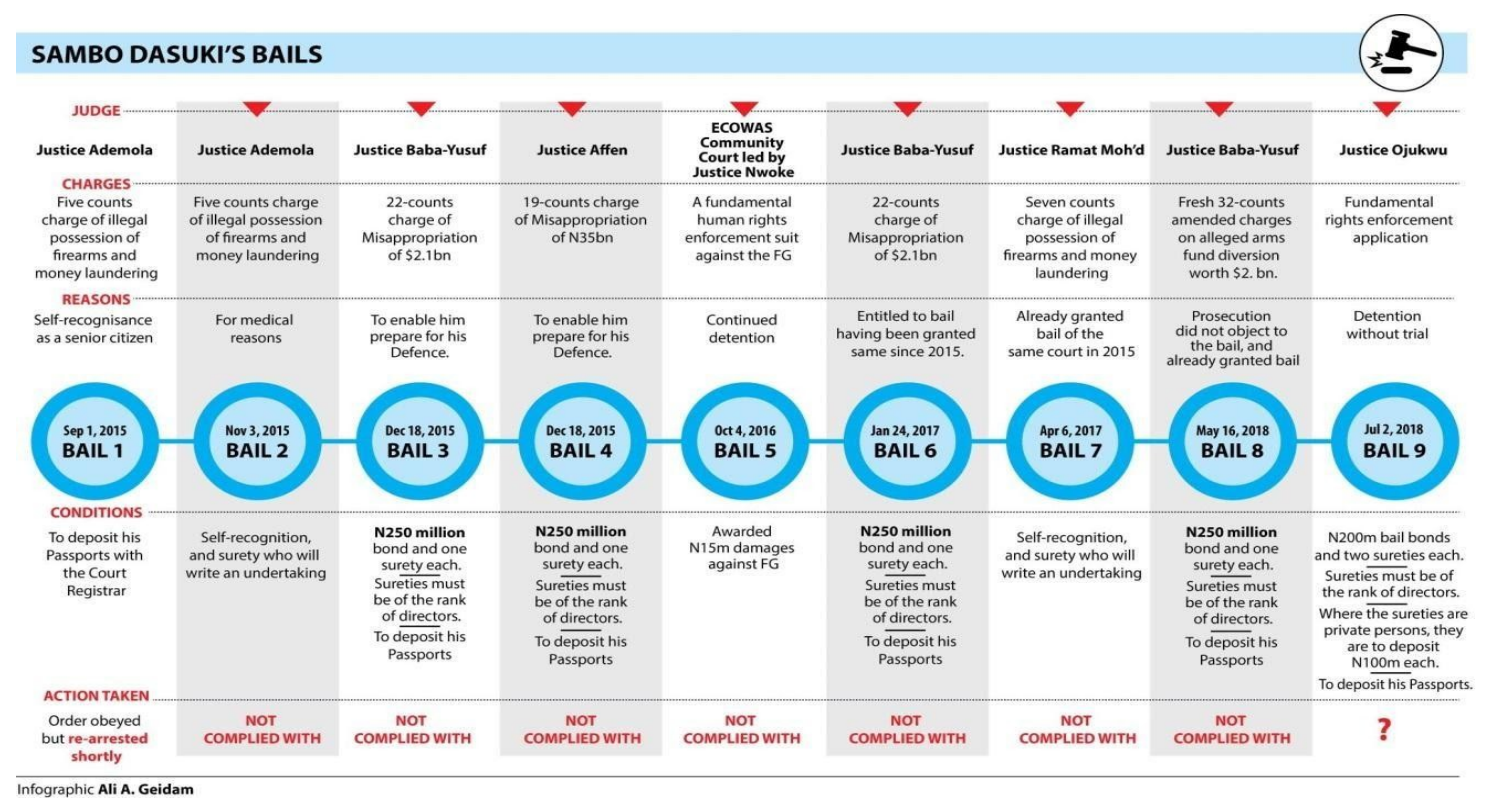

Figure 1

\section{References}

Abubakre, F. I. (2017). Press Framing of Anti-Corruption War on Buhari’s First Year Anniversary. Journal of Media Critiques, 3(12), 179-191. doi: 10.17349/jmc117410

Ani, M., \& Anyadike, D. (2013). Concepts and Emerging Theories: An Analysis of Editorials in Nigerian Newspapers. New Media and Mass Communication, 14(1), 1-6.

Ayres, L., Kavanaugh, K., \& Knafl, K. A. (2003). Within-Case and Across-Case Approaches to Qualitative Data Analysis. Qualitative Health Research, 13(6), 871-883. doi: 10.1177/1049732303013006008

Baran, S. J., \& Davis, D. K. (2010). Mass Communication Theory: Foundations, Ferment and Future with InfoTrac College Edition. Boston: Wadsworth Cengage Learning.

Boukes, M., Boomgaarden, H. G., Moorman, M., \& de Vreese, C. H. (2015). Political News with a Personal Touch: How Human Interest Framing Indirectly Affects Policy Attitudes. Fournalism \& Mass Communication Quarterly, 92(1), 121-141. doi: $10.1177 / 1077699014558554$

Brown, N. J., \& Udomisor, I. W. (2015). Evaluation of Political News Reportage in Nigeria's Vanguard and The Guardian Newspapers. Advances in fournalism and Communication, 03(01), 10-18. doi: 10.4236/ajc.2015.31002

Buhari's lawlessness: Our stand. (2019). Retrieved from Punch Newspapers website: https:// punchng.com/buharis-lawlessness-our-stand/

Cacciatore, M. A., Scheufele, D. A., \& Iyengar, S. (2016). The End of Framing as we Know it ... and the Future of Media Effects. Mass Communication and Society, 19(1), 7-23. doi: $10.1080 / 15205436.2015 .1068811$ 
Chime-Nganya, C. R., Ezegwu, D. T., \& Ezeji, A. (2017). Analysis of Nigerian Newspapers Framing of President Mohammadu Buhari's Medical Leave to United Kingdom. Media and Communication Currents, 1(2), 39-56.

Ciboh, R. S. (2007). Mass Media in Nigeria: Perspectives on Growth and Development. Ibadan: Aboki Publishers.

Country Reports on Human Rights Practices. (2018). Retrieved from United States Department of State. Bureau of Democracy, Human Rights and Labor website: https:// www.state.gov/reports/2018-country-reports-on-human-rights-practices/

Daramola, I. (2015). Mass Media and Social Change: A Discourse of the 2014 Ekiti State Governorship Election in Nigeria. Journal of Communication and Media Research, 7(2), $145-160$.

DSS Re-Arrests, Detains Sowore. (2019). Retrieved from Channels Television website: https://www.channelstv.com/2019/12/06/breaking-dss-re-arrest-sowore-on-freshcharges/

Duyile, D. (2005). Writing For the Media - A Manual for African fournalists. Lagos: Educational and Services Trust.

Ekeanyanwu, N. T. (2009). Analysis of the Content of Nigeria's Newspaper Editorials. Oko Journal of Communication \& Information Science, 1(2), 74-103.

Elyazale, N. (2014). Characteristics of Newspaper Editorials:'Chouftchouf' in 'Almassae'Moroccan Newspaper as a Case Study. New Media and Mass Communication, 32(1), 2143.

Emery, E. (1962). A history of American press. New York: Dodd, Mead \& Company, Inc.

Entman, R. M. (1993). Framing: Toward Clarification of a Fractured Paradigm. fournal of Communication, 43(4), 51-58.

Ewang, A. (2019, November 26). Nigerians Should Say No to Social Media Bill. Retrieved from Human Rights Watch website: https:/www.hrw.org/news/2019/11/26/nigerians-should-say-no-social-media-bill

Hassan, H. I. (2012). Giving attention to prominence, frequency and adequacy in the print media coverage of the Boko Haram Crisis. Fournal of Religious Studies, 34(33), 1-20.

Ikenna, O. (2008). Print media coverage of crisis. Journal of Conflict Management, 11(10), 7078.

Izadi, F., \& Saghaye-Biria, H. (2007). A Discourse Analysis of Elite American Newspaper Editorials: The Case of Iran's Nuclear Program. Journal of Communication Inquiry, 31(2), 140-165. doi: 10.1177/0 196859906298073

Mboso, A. G., \& Ezeh, N. C. (2019). Be Alert and Defend Yourselves: News Framing of Danjuma's Comments on Herdsmen Attacks in Nigeria. Galactica Media: Fournal of Media Studies, 1(3), 139-154. doi: 10.24411/2658-7734-2019-10 028

Nigeria: Climate of permanent violence. (n.d.). Retrieved from Reporters Without Borders website: https://rsf.org/en/nigeria 
Nigeria: Human rights agenda. (2019). Retrieved from Amnesty International website: https://www.amnesty.org/en/documents/document/? indexNumber $=$ afr $44 \% 2 f 0431 \% 2 f 2019 \&$ language $=e n$

Nigerian publisher Agba Jalingo charged with treason. (2019, September 5). Retrieved from Committee to Protect Journalists website: https://cpj.org/2019/09/nigerian-publisheragba-jalingo-charged-with-treas/

Njoku, N. A. (2010). Print media coverage of religious crisis in Nigeria. fournal of Religion and Conflict Studies, 9(7), 51-67.

Obiorah, C., \& Onwughalu, V. C. (2018). Democracy and Human Rights Governance in Nigeria under President Muhammadu Buhari: A fournalistic Perspective. Presented at the The 31st National Conference Of The Nigerian Political Science Association (Npsa), Held At The International Conference Centre Abakaliki, Ebonyi State, Ebonyi State. Nigeria.

Odoemelam, C. C., Ncube, J. B., \& Okorom, E. (2014). Frames in News Discourse on Nelson Mandela's illness and Hospitalisation: A Study of Nigerian and Zimbabwean Newspapers. New Media and Mass Communication, 29, 51-59. doi: 10.7176/NMMC.vol2951-59

Ogbondah, C. (2011). A critical analysis of state-press relations in Nigeria, 1999-2005. In L. Oso \& U. Pate (Eds.), Mass Media and Society in Nigeria (pp. 25-48). Lagos: Malthouse Press Limited.

OHCHR | Resolutions on good governance and human rights. (2012). Retrieved January 15, 2021, from United Nations Commission For Human Rights website: https://www.ohchr.org/EN/Issues/Development/GoodGovernance/Pages/Resolutions.aspx

Okorie, N., \& Oyedepo, T. (2011). Newspaper Reportage and its Effect towards Promoting Agricultural Development in Nigeria. Journal of Media and Communication Studies, 3(2), 27-32.

Olorede, J., Oyewole, A., \& Azeez, L. (2013). Press reportage of president Yar'adua's ill health: A study. New Media and Mass Communication, 9, 18-26.

Papacharissi, Z., \& Olivera, M. (2008). News frames terrorism: A comparative analysis of frame employed in terrorism coverage in US and United Kingdom newspapers. Press/Politics. New York: Sage Publication.

Scheufele, D. A., \& Tewksbury, D. (2007). Framing, agenda setting, and priming: The evolution of three media effects models. Journal of Communication, 57(1), 9-20. doi: 10.1111/j.1460-2466.2006.00326_5.x

That PUNCH editorial. (2019). Retrieved from Daily Trust website: https://dailytrust.com/ that-punch-editorial

We Released Sowore, Dasuki On Compassionate Grounds, Says Malami. (2019). Retrieved from Channels Television website: https:/www.channelstv.com/2019/12/27/we-released-sowore-dasuki-on-compassionate-grounds-says-malami/ 


\section{Список литературы}

Abubakre, F. I. (2017). Press Framing of Anti-Corruption War on Buhari's First Year Anniversary. Fournal of Media Critiques, 3(12), 179-191. doi: 10.17349/jmc117410

Ani, M., \& Anyadike, D. (2013). Concepts and Emerging Theories: An Analysis of Editorials in Nigerian Newspapers. New Media and Mass Communication, 14(1), 1-6.

Ayres, L., Kavanaugh, K., \& Knafl, K. A. (2003). Within-Case and Across-Case Approaches to Qualitative Data Analysis. Qualitative Health Research, 13(6), 871-883. doi: 10.1177/1049732303013006008

Baran, S. J., \& Davis, D. K. (2010). Mass Communication Theory: Foundations, Ferment and Future with InfoTrac College Edition. Boston: Wadsworth Cengage Learning.

Boukes, M., Boomgaarden, H. G., Moorman, M., \& de Vreese, C. H. (2015). Political News with a Personal Touch: How Human Interest Framing Indirectly Affects Policy Attitudes. Fournalism \& Mass Communication Quarterly, 92(1), 121-141. doi: $10.1177 / 1077699014558554$

Brown, N. J., \& Udomisor, I. W. (2015). Evaluation of Political News Reportage in Nigeria's Vanguard and The Guardian Newspapers. Advances in fournalism and Communication, 03(01), 10-18. doi: 10.4236/ajc.2015.31002

Buhari's lawlessness: Our stand. (2019). Retrieved from Punch Newspapers website: https:// punchng.com/buharis-lawlessness-our-stand/

Cacciatore, M. A., Scheufele, D. A., \& Iyengar, S. (2016). The End of Framing as we Know it ... and the Future of Media Effects. Mass Communication and Society, 19(1), 7-23. doi: $10.1080 / 15205436.2015 .1068811$

Chime-Nganya, C. R., Ezegwu, D. T., \& Ezeji, A. (2017). Analysis of Nigerian Newspapers Framing of President Mohammadu Buhari's Medical Leave to United Kingdom. Media and Communication Currents, 1(2), 39-56.

Ciboh, R. S. (2007). Mass Media in Nigeria: Perspectives on Growth and Development. Ibadan: Aboki Publishers.

Country Reports on Human Rights Practices. (2018). Retrieved from United States Department of State. Bureau of Democracy, Human Rights and Labor website: https:// www.state.gov/reports/2018-country-reports-on-human-rights-practices/

Daramola, I. (2015). Mass Media and Social Change: A Discourse of the 2014 Ekiti State Governorship Election in Nigeria. Journal of Communication and Media Research, 7(2), $145-160$.

DSS Re-Arrests, Detains Sowore. (2019). Retrieved from Channels Television website: https:/www.channelstv.com/2019/12/06/breaking-dss-re-arrest-sowore-on-freshcharges/

Duyile, D. (2005). Writing For the Media - A Manual for African fournalists. Lagos: Educational and Services Trust.

Ekeanyanwu, N. T. (2009). Analysis of the Content of Nigeria's Newspaper Editorials. Oko Journal of Communication \& Information Science, 1(2), 74-103. 
Elyazale, N. (2014). Characteristics of Newspaper Editorials:'Chouftchouf'in 'Almassae'Moroccan Newspaper as a Case Study. New Media and Mass Communication, 32(1), 2143.

Emery, E. (1962). A history of American press. New York: Dodd, Mead \& Company, Inc.

Entman, R. M. (1993). Framing: Toward Clarification of a Fractured Paradigm. fournal of Communication, 43(4), 51-58.

Ewang, A. (2019, November 26). Nigerians Should Say No to Social Media Bill. Retrieved from Human Rights Watch website: https:/www.hrw.org/news/2019/11/26/nigerians-should-say-no-social-media-bill

Hassan, H. I. (2012). Giving attention to prominence, frequency and adequacy in the print media coverage of the Boko Haram Crisis. Fournal of Religious Studies, 34(33), 1-20.

Ikenna, O. (2008). Print media coverage of crisis. Journal of Conflict Management, 11(10), 7078.

Izadi, F., \& Saghaye-Biria, H. (2007). A Discourse Analysis of Elite American Newspaper Editorials: The Case of Iran's Nuclear Program. Journal of Communication Inquiry, 31(2), 140-165. doi: 10.1177/0 196859906298073

Mboso, A. G., \& Ezeh, N. C. (2019). Be Alert and Defend Yourselves: News Framing of Danjuma's Comments on Herdsmen Attacks in Nigeria. Galactica Media: Fournal of Media Studies, 1(3), 139-154. doi: 10.24411/2658-7734-2019-10028

Nigeria: Climate of permanent violence. (n.d.). Retrieved from Reporters Without Borders website: https://rsf.org/en/nigeria

Nigeria: Human rights agenda. (2019). Retrieved from Amnesty International website: https://www.amnesty.org/en/documents/document/? indexNumber $=$ afr $44 \% 2 f 0431 \% 2 f 2019$ \&language $=\mathrm{en}$

Nigerian publisher Agba Jalingo charged with treason. (2019, September 5). Retrieved from Committee to Protect Journalists website: https://cpj.org/2019/09/nigerian-publisheragba-jalingo-charged-with-treas/

Njoku, N. A. (2010). Print media coverage of religious crisis in Nigeria. Fournal of Religion and Conflict Studies, 9(7), 51-67.

Obiorah, C., \& Onwughalu, V. C. (2018). Democracy and Human Rights Governance in Nigeria under President Muhammadu Buhari: A Fournalistic Perspective. Presented at the The 31st National Conference Of The Nigerian Political Science Association (Npsa), Held At The International Conference Centre Abakaliki, Ebonyi State, Ebonyi State. Nigeria.

Odoemelam, C. C., Ncube, J. B., \& Okorom, E. (2014). Frames in News Discourse on Nelson Mandela's illness and Hospitalisation: A Study of Nigerian and Zimbabwean Newspapers. New Media and Mass Communication, 29, 51-59. doi: 10.7176/NMMC.vol2951-59

Ogbondah, C. (2011). A critical analysis of state-press relations in Nigeria, 1999-2005. In L. Oso \& U. Pate (Eds.), Mass Media and Society in Nigeria (pp. 25-48). Lagos: Malthouse Press Limited. 
OHCHR | Resolutions on good governance and human rights. (2012). Retrieved January 15, 2021, from United Nations Commission For Human Rights website: https://www.ohchr.org/EN/Issues/Development/GoodGovernance/Pages/Resolutions.aspx

Okorie, N., \& Oyedepo, T. (2011). Newspaper Reportage and its Effect towards Promoting Agricultural Development in Nigeria. Journal of Media and Communication Studies, $3(2), 27-32$.

Olorede, J., Oyewole, A., \& Azeez, L. (2013). Press reportage of president Yar'adua's ill health: A study. New Media and Mass Communication, 9, 18-26.

Papacharissi, Z., \& Olivera, M. (2008). News frames terrorism: A comparative analysis of frame employed in terrorism coverage in US and United Kingdom newspapers. Press/Politics. New York: Sage Publication.

Scheufele, D. A., \& Tewksbury, D. (2007). Framing, agenda setting, and priming: The evolution of three media effects models. Journal of Communication, 57(1), 9-20. doi: 10.1111/j.1460-2466.2006.00326_5.x

That PUNCH editorial. (2019). Retrieved from Daily Trust website: https://dailytrust.com/ that-punch-editorial

We Released Sowore, Dasuki On Compassionate Grounds, Says Malami. (2019). Retrieved from Channels Television website: https://www.channelstv.com/2019/12/27/we-released-sowore-dasuki-on-compassionate-grounds-says-malami/ 